\title{
Correlates of Job Satisfaction of Community School's Teachers of Phidim Municipality, Nepal
}

\author{
Laxmi Prasad Bhandari
}

Lecturer

Faculty of Education, Panchthar M. Campus, Phidim Panchthar, Tribhuvan University, Nepal laxmibhandari740@gmail.com

DOI: https://doi.org/10.3126/dristikon.v11i1.39143

\begin{abstract}
Teachers' satisfaction is a significant concern of the overall education system of a country. This study examines the factors influencing job satisfaction of community school teachers' of Phidim Municipality. More specifically, this paper aims to investigate whether the sex of the teacher, income, nature of the job, age, birthplace, religion and educational status affect teachers' job satisfaction or not. This study is a cross sectional survey where sample size is determined by using Slovin's formula and the data were drawn from a self-administered questionnaire from randomly selected community school teachers. The percentages, Chi-Square test, and binomial logistic regression model were used for univariate, bivariate, and multivariate analysis using SPSS. The yearly income, age of teachers, and nature of job were found significantly associated with teachers' satisfaction under bivariate analysis whereas the binomial logistic regression justified the association of teachers' satisfaction to income of teachers and nature of their job only. The association of teacher's satisfaction to the sex of respondent, religion, educational status, and birthplace were found not significant using both bivariate and multivariate analysis. It is the conclusion that the permanency of job and reasonable salary must be managed mainly to make teacher's satisfied. In the present Nepalese context, the adjustment of teacher's salary as per the changing cost of living figure is necessary for teacher's job satisfaction. Likewise, the formulation of the teacher service commission as constitutional body, and regular operation of examination for teacher's permanent recruitment can enhance teacher's job satisfaction.
\end{abstract}

Keywords: educational status, cross sectional survey, Slovin's formula, effectiveness, nature of job 


\section{Introduction}

Education is the basic infrastructure for developing a country. The teacher is an important factor in the education system. The role of teachers in education can change, but the importance of their position remains the same. It is a great challenge for educational institutions to attract and retain quality teachers. If the teachers have got high job satisfaction, the educational institutions can attract and retain quality teachers otherwise they cannot.

Job satisfaction is a positive or pleasant emotional state resulting from a person's appreciation of his/her job or experience. Job satisfaction is the relationship between what everyone expects in accordance with what everyone achieves (Locke, 1976, as cited in Demirtas, 2010). Any work cannot be done without satisfaction. School teachers are important in building the manpower of the nation. If they have satisfaction in their job, the society's wellbeing can be possible. Job satisfaction is a factor that will ensure class performance and productivity of schools. The teachers would get interested to teach their students effectively when they are satisfied with their job (Nigama et al., 2018).

Toropova et al. (2020) stated that job satisfaction is closely related to teachers' retention. It also contributes to the well-being of teachers and their students, overall school cohesion, and enhances the status of the teaching profession.

The underlying factors affecting the job satisfaction of community school teachers need investigation and exploration in the context of Nepal to be better understood and appropriately addressed by the related authorities. It is essential to identify these factors by those who are at the administrative, managerial, and policy formulating levels of the education system. To develop effective strategies for increasing teaching-learning outcomes, it is necessary to understand the factors affecting the job satisfaction of community school teachers in Nepalese context. The findings of this study aim to guide education planners and policymakers to understand various factors influencing job satisfaction of school teachers and assist in the implementation of the learning outcomes increasing program which will promote the overall educational achievement. Moreover, program planners and policymakers can focus on some particular aspects of the educational program and improve the effectiveness of educational activities by identifying the job satisfaction of teachers. If teacher's job satisfaction is high, then it is expected that they will do their job with full effort and happiness and learning outcomes can be increased, and the overall educational status of the community can be improved with an appropriate teaching-learning environment. Though there are very few studies about the job satisfaction of community school teachers in Nepal, this type of research will contribute to educational reform. 


\section{The Objective of the Study}

The objective of this research was to find out the correlates of satisfaction level of community school teachers of Phidim municipality. In line with this objective, it had been researched whether teacher's job satisfaction shows any connection to their sex, age, income, nature of job, birthplace, religion, and qualification.

\section{The Rationale of the Study}

The role of teachers in society is very important. A teacher who is satisfied with his/her job can perform his/her work effectively and efficiently. If the teacher work under stress, they cannot be satisfied with their job and it will create a negative impact on the job. It is necessary to identify the factors that influence the teacher's satisfaction in Nepalese context also. This study is important because it has compared the job satisfaction of male and female teachers and it has studied some demographic and socio-economic factors which can affect job satisfaction. This study had aimed to explore the correlates of job satisfaction among teachers of community schools in Phidim municipality, Nepal.

\section{Literature Review}

This study is about the job satisfaction of teachers. Job satisfaction is one of the most widely researched subjects in the world. This study can get support from the findings of the previous researches. So, the findings of some previous researches are discussed in this section. Klassen et al. (2009), and Skaalvik and Skaalvik (2010) had focused on self-efficacy of teachers for job satisfaction and stated that self-efficacious teachers can plan, organize and execute specific teaching-related tasks required to attain desired levels of performance and may foster the development of later satisfaction from corresponding accomplishments. Granziera and Perera (2019) have also focused on self-efficacy and concluded that higher self-efficacy yields higher satisfaction of teachers or high level of self-efficacy experience greater work satisfaction. Lent and Brown (2006) have concluded that individual's participation in goal-directed activity, encompassing their engagement with the work-related task, fosters work satisfaction.

Job satisfaction is any combination of psychological, physiological, and environmental circumstances that cause a person truthfully to say I am happy with my job (Hoppock, 1935 as cited in Lester, 1987). Ariffin et al. (2013) stated that there is difficulty in defining job satisfaction. Identification of factors affecting job satisfaction is also problematic. Discrepancies among studies occur because individuals have varying attitudes and values systems, perceive different aspects of the work situation, and take into consideration different factors (Ariffin et al., 2013). Koutouzis and Malliara (2017) had focused on the effect of principal's leadership and decision-making style relating to teacher's job satisfaction. Doing a study on Greek teachers, they concluded that teachers' job satisfaction is a factor that significantly affects many aspects of quality in education. There is a relationship between the 
principal's decision-making style and his/her leadership style. The transformational leadership style relates positively to teacher's job satisfaction whereas the transactional style relates negatively. In order to increase teachers' job satisfaction, principals should use a mix of different leadership styles and decision-making styles that respond better to each situation.

Nguni et al. (2006) stated that teachers are recognized as key factors that significantly affect the quality of education. So, the teacher's role is significantly highlighted. For teachers to fulfill their demanding role, it is necessary for them to feel good about their job and draw satisfaction from it. Satisfied teachers work more effectively. So, improving teachers' job satisfaction is very much important. Satisfied teachers tend to be more enthusiastic and willing to invest more time and energy in educating students Koutselios (2001) has stated four factors affecting the job satisfaction of teachers. They are working conditions, recognition by students and parents, meritocracy, and recognition by colleagues and principles.

Hui et al. (2013) argued that there is a relationship between teachers' job satisfaction and principal's decision-making style. Hariri (2011) has stated that transformational leaders pay attention to individual needs, so this leadership style leads to a higher level of performance and job satisfaction. Transactional leaders' behavior harms employees' job satisfaction (Nguni et al., 2006). There is a relationship between job satisfaction and life satisfaction (Ho \& $\mathrm{Au}, 2008$ as cited in Demirtas, 2010).

Chapman and Lowther (1982) proposed a conceptual scheme of the influences affecting teachers' career satisfaction and completed a study using that scheme to investigate the relationship between selected abilities, values, and accomplishments and teachers' career satisfaction. They found that specifically women were more satisfied with their teaching career than men. Teachers' skills and abilities were significantly related to satisfaction but accounted for only small amounts of the additional variance. Nigama et al. (2018) studied the satisfaction among government and private school teachers and found that there is no significant difference in their level of satisfaction irrespective of gender. They further concluded that organizational support towards teachers in enhancing job satisfaction is very important. Freedom at the workplace, creation of self-motivated teams at school, self-developmental opportunities, shortterm courses, seminars, workshops, high appreciation, and rewards for commendable work are the ways to improve job satisfaction.

Toropova et al. (2020) concluded that there is a substantial association between school working conditions and teachers' job satisfaction. More specifically teachers' workload, teacher cooperation, and teacher perceptions of student discipline in school were the factors most closely related to teacher job satisfaction in their study. As to teacher characteristics, female teachers, teachers with more exposure to professional development, and more efficacious teachers tended to have higher levels of job satisfaction. In addition, it was found that the 
relationship between the extent of teacher cooperation and job satisfaction was more pronounced for male teachers, while student discipline was more important for the job satisfaction of teachers with lower self-efficacy beliefs.

Demirtas (2010) had measured the primary school teachers' job satisfaction levels in Elazig city center of Turkey. Using teachers' satisfaction survey as a data collection technique, he found that in terms of an age difference there is a meaningful difference in average job satisfaction. The teachers of age group 36-40 had the highest average and the group of 41 and above age has the lowest averages. He found no meaningful differences in job satisfaction in terms of the professional seniority and the branch of teaching variables. Hughes (2016) examined job satisfaction among teachers in the Techiman Municipality of Ghana. She had concluded from her research that many teachers in the Techiman Municipality perceived teaching as their ideal profession but most teachers will prefer to change their profession as a result of dissatisfaction. Also, teachers felt their conditions of service not good enough and most teachers in the Municipality felt dissatisfied with security in the profession.

Persevica (2011) researched in Latvia who had concluded that teachers are mostly satisfied with the chosen profession. She analyzed the identified correlations between job satisfaction and quality of education which showed that there is a significant correlation between several levels of interpersonal relationships and various aspects of quality. She highlighted the importance of teachers' emotional feelings in the process of assuring quality education.

\section{Materials and Methods}

This is the cross-sectional study conducted at Phidim municipality of eastern Nepal. This study was conducted among the teachers of community schools, who are the population for this study. I had collected the accumulated record of teachers from the Education Branch of Phidim Municipality and Education Development and Coordination Unit of Panchthar district. According to those records, total teachers except Sahayogi Karyakarta (Sa. Ka.) of Child Development Centre were 434 and Sa. Ka. were 75. So, the total population of my research was 509. I have calculated the sample size by using Slovin's formula (Ellen, 2021). The formula is the Sample size $(\mathrm{n})=\mathrm{N} \div\left(1+N e^{2}\right)$. By assuming a $5 \%$ error tolerance, the calculated sample size was 224 . The sample size is $44.01 \%$ of the population here. There were fourteen wards in Phidim municipality. So, I had selected seven of the wards randomly using a lottery method. Again I had made a list of all community school teachers of those seven wards indicating serial numbers and selected 224 teachers out of them using a random number table. Those 224 teachers were my respondents.

I had used a self-administered questionnaire including nineteen questions for collecting data from respondents. In that questionnaire, the different information related to educational, 
demographic, social, and economic aspects of the respondents were asked. I had sent the questionnaire to randomly selected respondents and collected them after filling it up. My exstudents of master's degree (now teachers at different schools of my research site) helped me to distribute and collect the questionnaire.

After collecting those filled-up questionnaires from respondents, I had recorded the entire information in SPSS. I had used SPSS for univariate, bivariate, and multivariate analysis. Chi-square test and phi were used for bivariate analysis and binary logistic equation was used for multivariate analysis. This paper analyzed the level of job satisfaction of teachers of community schools. So, job satisfaction was the dependent variable. The job satisfaction was expressed on an ordinal scale and there were five satisfaction levels in order. The different demographic and socioeconomic factors included in the questionnaire were independent variables.

\section{Results and Discussion}

Among surveyed teachers, less than half (46\% out of 224) were female and remaining were male. Approximately $90 \%$ teachers had their permanent residence in the home district Panchthar and the remaining teachers were from other districts. Besides the home district, more teachers were from Jhapa (4\%) than other districts. I had collected the data of the age of respondent on a ratio scale and entered the same in SPSS but I recoded the age in three classes as up to 30, 31-45, and above 45 during bivariate analysis. The highest number of teachers were of the age group 31-45 and only one teacher was of age below 20. Slightly less than half $(48.7 \%)$ teachers were of age groups $31-45$, less than one fourth $(24.1 \%)$ were of age up to 30 and more than one fourth $(27.2 \%)$ were of age more than 45 years.

Among all teachers, about five out of nine (54.9\%) had followed Hinduism. Three out of eight had followed Kirat religion, one out of fifteen (6.7 \%) were Buddhist and about $1 \%$ of teachers were Christian. More than two-fifths (42.9\%) of teachers had permanency of their job. The government-funded temporary teachers including $\mathrm{Sa}$. Ka. of child development center were $45.1 \%$ and $12 \%$ were others like school-funded (Niji). I had also included the question related to the educational status of respondents. According to the response, slightly more than onefourth $(27.7 \%)$ of teachers had qualifications up to SLC. Likewise, more than one-fourth of teachers $(26.8 \%)$ had the qualifications of intermediate level. The teachers having qualification of bachelor level and Master's level were both more than one-fifth (22.3\% and $22.2 \%)$ respectively. No one was having qualifications above master's degree level. I had included the question for satisfaction level for qualification of teachers. Less than one-tenth (7.6\%) of the teachers were very satisfied with their qualification and slightly less than six out of ten $(56.7 \%)$ teachers were satisfied. Less than one-tenth $(8.9 \%)$ were neither satisfied nor dissatisfied with their qualification and slightly more than one-fourth $(26.8 \%)$ were dissatisfied with their 
qualification. No one was very dissatisfied with his/her qualification. In response to educational status more than two-fifth (43.5\%) of teachers desired to study more, about three out of ten $(30.6 \%)$ stated that the qualification they hold was ok for them. About one-tenth had the view that they had no opportunity for study. There were other responses also which were in low proportion. I had included a question about yearly income also. The mean yearly income was found

Rs 3,27,610.80, the standard deviation of income was 139320.48 . The highest income was $7,00,000$ and the lowest income was rupees 38000 only. Slightly less than four out of ten $(37.1 \%)$ teachers had yearly income below average income and more than six out of ten $(62.9 \%)$ teachers had yearly income above average income.

I had collected information on the satisfaction level of teachers. This represents the dependent variable in this study. About one out of seven (14.3\%) teachers were found very satisfied with their job. About six out of ten (58.9\%) were satisfied only not very satisfied, $8 \%$ of teachers were neither satisfied nor dissatisfied, $16.5 \%$ were dissatisfied and only five teachers out of 224 were very dissatisfied. Satisfied teachers mentioned the causes of satisfaction like a government job (27\%), area of interest (14.5\%), social service (6.5\%), the base for livelihood (15.3\%), respectable job (3.1\%), site near home (16\%) permanency $(3.8 \%)$ and intellectual field $(1.1 \%)$. One teacher out of 224 had given the cause for job satisfaction as an opportunity to be a teacher at a self-studied School. The dissatisfied teachers mentioned the causes of dissatisfaction as non-permanency (15.6\%), low salary (15.3\%), poor facility (1.9\%), far from home $(3.1 \%)$. One male teacher said that he was satisfied because he had got the opportunity till old age and another one said that he was not satisfied because of no respect from others to the teaching profession. This shows that there are more teachers getting respect in the profession than not getting respect.

\section{Table 1}

Background Characteristics

\begin{tabular}{llc}
\hline Baseline characteristics & Number & \% \\
\hline Sex & 103 & 46 \\
Female & 121 & 54 \\
Male & & \\
Birth place & 196 & 87.5 \\
$\quad$ Panchthar (home district) & 28 & 12.5 \\
Others & & \\
Age & 54 & 24.1 \\
Up to 30 & 109 & 48.7 \\
31-45 & &
\end{tabular}


Above 45

Religion

Hindu

Kirat

Buddhist

Christian

Nature of job

Permanent

Temporary (Govt. funded)

Others

Satisfaction with Job

\begin{tabular}{lll} 
Very satisfied & 32 & 14.3 \\
Satisfied & 132 & 58.9 \\
Neither satisfied nor dissatisfied & 18 & 8 \\
Dissatisfied & 37 & 16.5 \\
Very dissatisfied & 5 & 2.2 \\
\hline Baseline characteristics & Number & \% \\
\hline Education Status & & \\
Up to SLC & 62 & 27.7 \\
Intermediate or 10+2 & 60 & 26.8 \\
Bachelor & 50 & 22.3 \\
Masters & 52 & 23.2 \\
Satisfaction with Education Status & & 7.6 \\
Very Satisfied & 17 & 56.7 \\
Satisfied & 127 & 8.9 \\
Neither satisfied nor dissatisfied & 20 & 26.8 \\
Dissatisfied & 60 & 37.1 \\
Yearly Income & & 62.9 \\
Up to average (Rs327610.80) & 83 & \\
More than average & 141 &
\end{tabular}

\section{Bivariate Analysis}

I have tested the association of teachers' job satisfaction to their yearly income, age, nature of job, sex, birthplace, educational status, and religion using the Chi-square test at 5\%, and $1 \%$ level of significance.

\section{Table 2}

Job Satisfaction of Community School's Teachers According to Background Characteristics 


\begin{tabular}{|c|c|c|c|c|}
\hline & Satisfied & Neither & \multicolumn{2}{|c|}{ Dissatisfied Number } \\
\hline Sex & \multicolumn{2}{|c|}{ NS } & & \\
\hline Female & $68.9 \%$ & $5.8 \%$ & $25.2 \%$ & 103 \\
\hline Male & $76.9 \%$ & $9.9 \%$ & $13.2 \%$ & 103 \\
\hline Age & \multicolumn{2}{|c|}{ \#\#\# } & & \\
\hline Upto 30 years & 57.4 & 7.4 & 35.2 & 54 \\
\hline $31-45$ years & 72.5 & 11.0 & 16.5 & 109 \\
\hline Above 45 years & 88.5 & 3.3 & 8.2 & 61 \\
\hline Nature of Job & \multicolumn{2}{|c|}{ \#\#\# } & & \\
\hline Permanent & 92.7 & 4.2 & 3.1 & 96 \\
\hline Temporary (Govt. funded) & 62.4 & 11.9 & 25.7 & 92 \\
\hline Others & 44.4 & 7.4 & 48.1 & 36 \\
\hline Educational Status & \multicolumn{2}{|c|}{ NS } & & \\
\hline Upto SLC & 71 & 4.8 & 24.2 & 62 \\
\hline Intermediate or $10+2$ & 65 & 8.3 & 26.7 & 60 \\
\hline Bachelor & 78 & 8 & 14 & 50 \\
\hline Masters & 80.8 & 11.5 & 7.7 & 52 \\
\hline Yearly Income & \#\#\# & & & \\
\hline \multicolumn{2}{|c|}{ Upto average income (Rs327610.80) 49.4} & 8.4 & 42.2 & 83 \\
\hline More than average & 87.2 & 7.8 & 5 & 141 \\
\hline Birth Place & \multicolumn{2}{|c|}{ NS } & & \\
\hline Panchthar & 74 & 7.7 & 18.4 & 196 \\
\hline Others & 67.9 & 10.7 & 21.4 & 28 \\
\hline Religion & \multicolumn{2}{|c|}{ NS } & & \\
\hline Hindu & 79.7 & 8.1 & 12.2 & 123 \\
\hline Kirat & 67.9 & 7.1 & 25.0 & 84 \\
\hline Others & 52.9 & 11.8 & 35.3 & 17 \\
\hline
\end{tabular}

Note. $\# \# \#=$ Significant at $\mathrm{p}<0.001, \# \#=\mathrm{p}<0.01$ and $\#=\mathrm{p}<0.05, \mathrm{NS}=$ not significant.

Association of teachers' satisfaction and their income. When testing the association of teacher's satisfaction with their income, I had recoded the variable yearly income and made two categories. One of them was up to average income (which was Rs 327610.80) and the another was above average income. The satisfaction level was recoded in three categories as satisfied, neither satisfied nor dissatisfied, and dissatisfied. About half (49.4\%) teachers earning average income or less were satisfied, less than one out of ten $(8.4 \%)$ were neither satisfied nor dissatisfied and $42.2 \%$ were dissatisfied. On the other hand, $87.2 \%$ of teachers earning more than average income were satisfied, $7.8 \%$ were neither satisfied nor dissatisfied and $5 \%$ only were dissatisfied. This shows a high satisfaction level in the high-income group. 
For the testing association, Chi-square was calculated. The value of Chi-square was 48.810 and the p-value was 0.000 . It was below 0.01 , which shows that the association of satisfaction of teachers and their income was statistically significant at $1 \%$ error of tolerance. The value of phi was 0.467 or $(0.3<p h i<0.5)$ which showed the moderate strength of association or the moderate effect size. There was neither higher nor lower but moderate level relationship between teacher's satisfaction and their income.

Association of teachers' satisfaction and their age. I had tested the association of satisfaction of teachers to their age also. For that purpose, satisfaction level had above stated three categories and age was also recoded in three groups as up to 30,31-45 and above 45. In up to 30 years' age group, slightly less than three fifths (57.4\%) were satisfied. Likewise, in the 31-45 years' age group, more than seven out of ten (72.5\%) were satisfied, and in the above 45 years' group, about nine out of ten $(88.5 \%)$ were satisfied. This showed that the satisfaction proportion was increased with an increase in the age of teachers. On the other hand, neither satisfied nor dissatisfied teachers in these three age groups were $7.4 \%, 11 \%$, and $3.3 \%$ respectively. And dissatisfied teachers in these three age groups were $35.2 \%, 16.5 \%$, and $8.2 \%$ respectively. The proportion of dissatisfied teachers had decreased with an increase in age.

The percentages showed there was an association of age group with teachers' satisfaction level. For testing significance of association, I used Chi-Square. The value of Chisquare was found 18.441 and the p-value was 0.001 , which showed the association was significant with $5 \%$ error of tolerance. The value of phi was found 0.287 or $(0.1<p h i<$ 0.3 ) which showed the modest strength of association or the modest effect size. There was less than moderate but modest level relationship between teacher's satisfaction and their age.

Association of teachers' satisfaction and nature of the job. I had tested the association of satisfaction of teachers to the nature of their job also. For that purpose, satisfaction level had above stated three categories and the nature of the job was recoded in three groups as permanent teachers, government-funded temporary teachers, and others. The group 'others' included school funded and other teachers. The calculation showed that more than nine out of ten $(92.7 \%)$ of permanent teachers were satisfied, $4.2 \%$ of them were neither satisfied nor dissatisfied and $3.1 \%$ were dissatisfied. Likewise in the case of governmentfunded temporary teachers, $64.1 \%$ were satisfied, $12 \%$ were neither satisfied nor dissatisfied and $23.9 \%$ were dissatisfied. In the 'others' group, $44.4 \%$ were satisfied, $8.3 \%$ were neither satisfied nor dissatisfied and $47.2 \%$ were dissatisfied.

This showed that the satisfied proportion of permanent teachers was very high and that of non-permanent was low. There was the association of teachers' permanency or nature of the job with teachers' satisfaction level. To test the significance of association, Chi-square was calculated. The value of Chi-square was found at 43.015 and the p-value was 0.000 which 
showed the significance of association at a $1 \%$ error tolerance level. The phi value was 0.438 which showed moderate strength of association or the moderate effect size.

On the other hand, the association of teacher's satisfaction to sex, birthplace, religion, and educational status were also studied using the Chi-square test, which was found nonsignificant. Their $\mathrm{p}$ values were $0.052,0.766,0.052$, and 0.137 respectively which were more than cut-off point 0.05 . So, there was not any association of teacher's satisfaction to sex, birthplace, religion, and educational status.

Among the variables studied, teacher's income, age, and nature of job were found associated with teacher's satisfaction. But the association with sex, marital status, religion, and educational status was found non-significant. Chapman and Lowther (1982) had claimed female teachers' get more satisfaction than male but the finding of this study contradicts with them.

\section{Multivariate Analysis}

I had to test whether teachers' satisfaction can be predicted based on their age, nature of the job, and income. For using binomial logistic regression, the dependent variable must be dichotomous. I had recoded the teachers' satisfaction dichotomous by making two groups as satisfied and others. The independent variables were age, nature of the job, and income.

\section{Table 3}

Adjusted Odds Ratio from Logistic Regression Model of Teachers' Satisfaction

\begin{tabular}{|c|c|c|c|c|c|}
\hline Selected predicators & Coefficients & Adj. OR sig. (p) & Exp. (B) & Lower & Upper \\
\hline Sex & 0.257 & $1.2940 .524 \mathrm{NS}$ & 1.294 & 0.586 & 2.857 \\
\hline Age & 0.028 & $1.0290 .236 \mathrm{NS}$ & 1.029 & 0.982 & 1.078 \\
\hline Birthplace & 0.286 & $\begin{array}{r}1.331 \\
\quad 3.680\end{array}$ & $0.581 \mathrm{NS}$ & 1.331 & 0.481 \\
\hline Yearly income & 0.000 & $1.0000 .016 \#$ & 1.000 & 1.000 & 1.000 \\
\hline Nature of job & -0.827 & 0.437 & $\begin{array}{l}0.010 \text { \#\# } \\
819\end{array}$ & 0.437 & 0.233 \\
\hline Religion 1 & 1.026 & $2.7890 .111 \mathrm{NS}$ & 2.789 & 0.790 & 9.851 \\
\hline Religion 2 & 0.688 & $1.9900 .289 \mathrm{NS}$ & 1.990 & 0.557 & 7.106 \\
\hline Educational Status & -0.142 & $0.8680 .513 \mathrm{NS}$ & 0.868 & 0.567 & 1.327 \\
\hline Constant & & -0.635 & & & \\
\hline Cox \& Snell R Square & & 0.202 & 293 & & \\
\hline
\end{tabular}


Note. \#\# Significant at $\mathrm{p}<0.01$, \# $=\mathrm{p}<0.05$ and $\mathrm{NS}=$ not significant

The coefficients of all variables along with their $\mathrm{p}$ values are important in above table which are calculated by using SPSS. The explained variation in the teachers' satisfaction (dependent variable) by independent variables on our model ranges from 20.2 to $29.3 \%$ depending on reference to the Cox \& Snell R square and Nagelkerke R square method respectively. Nagelkerke R square is the modification of Cox \& Snell R square, the latter of which cannot achieve a value of 1 . For this reason, it is preferable to report the Nagelkerke $\mathrm{R}$ square value. The classification table showed almost $76.3 \%$ correct classification. So, the model is not too bad. The discriminant analysis is better in classifying data correctly.

The variables in the table showed the contribution of each independent variable to the model and their statistical significance. The significance for the coefficients of the regression model is shown by the $\mathrm{p}$-value. The $\mathrm{p}$ values for nature of the job, and income are 0.010 and 0.016 respectively which shows that the association of teachers' satisfaction to nature of job and income is significant. On the other hand, the $\mathrm{p}$ values for sex, age, birthplace, religion, and educational status are more than significance level 0.05 . Therefore, the relation of teacher's satisfaction to sex, age, birthplace, religion, and educational status is not significant.

The study looked at the satisfaction level and factors influencing job satisfaction of community school teachers in Phidim municipality of eastern Nepal. The previous studies had shown various factors that affect the job satisfaction of teachers. Granziara and Perera (2019) have the view that self-efficacy affects the job satisfaction of teachers. Lester (1987) stated supervision, colleagues, working conditions, pay, responsibility, work itself, advancement, security, and recognition as factors affecting job satisfaction.

\section{Conclusion}

This study has analyzed different factors concerning job satisfaction of community school teachers and has found that the income, nature of the job, and age of teachers are associated with teachers' job satisfaction. More proportion of teachers having income more than average income are satisfied than teachers having an income equal to or less than average income. So, it is concluded that high income gives high job satisfaction than low income.

Likewise, teachers having more age are found more satisfied than teachers having less age and permanent teachers are found more satisfied than others. This has concluded that the permanency of teachers affects teachers' satisfaction positively and vice versa. The Chi-square test under bivariate analysis has justified that the association of teachers' satisfaction to their income, age, and nature of the job is significant. The effect size (denoted by phi) is maximum for income amongst these three variables. Therefore, it is concluded that income has the greater association than others. On the other hand, the association of teacher's satisfaction to sex, 
birthplace, religion, and educational status were also studied using the Chi-square test, which was found non-significant.

The binomial logistic regression under multivariate analysis also justifies the association of teachers' satisfaction to yearly income, and nature of the job because that has seen significant but the association of teachers' satisfaction to age, sex, birthplace, religion, and educational status are not justified by binary logistic regression.

\section{Implications}

The findings of this study can be beneficial to educational policy makers and administrators in Nepalese context to take effective actions for enhancing job satisfaction of community school's teachers. Since the permanency of job was found as a factor affecting teacher's job satisfaction, the formulation of the teacher service commission as constitutional organ is mandatory and the operation of examination for teacher's permanent recruitment must be regular. If there is regularity of such examination, the discrimination in remuneration among various types of teachers can be eliminated and the income of all teachers can be reasonable which can support to enhance teachers satisfaction. Furthermore, the adjustment of teacher's salary as per the changing cost of living figure can enhance teacher's job satisfaction. This study covered only seven independent variables; such as sex, age, birthplace, income, nature of job, religion and educational status. There can be other variables also affecting teacher's job satisfaction. The study included the teachers of community school only. Therefore, further research needs to be conduct by including other variables and including the teachers of institutional schools and higher levels also.

\section{References}

Ariffin, A., Hashim, H., \& Sueb, R. (2013, November 27). Identifying teacher's job satisfaction (Conference session). International Language and Education Conference 2013, University Sains Islam, Malaysia. https://www.researchget.net/publication/282062708

Chapman, D. W., \& Lowther, M. A. (1982). Teachers' satisfaction with teaching. The Journal of Educational Research, 75(4), 241-247. https://www.jstor.org/stable/27539902

Demirtas, Z. (2010). Teachers' job satisfaction levels. Procedia-Social and Behavioral Sciences, 9, 1069-1073. https://doi.org/10.1016/j.sbspro.2010.12.287

Ellen, S. (2021, May14). Slovin's Formula Sampling Techniques. Sciencing.com. https://sciencing.com/slovins-formula-sampling-techniques-5475547.html

Granziera, H. \& Perera, H. N. (2019). Relations among teachers' self-efficacy beliefs, engagement, and work satisfaction: A social cognitive view. Contemporary Educational Psychology, 58, 75-84. https://doi.org/10.1016/j.cedpsych.2019.02.003 
Hariri, H. (2011). Leadership styles, decision making styles, and teacher job satisfaction: An Indonesian school context (Doctoral dissertation, James Cook University). Leadership styles, decision-making styles, and teacher job satisfaction: an Indonesian school context - Research Online, JCU.

Hughes, W. A. (2016). Assessing the impact of teacher job satisfaction among teachers. Journal of Education and Practice, 7(30), 161-165. https://files.eric.ed.gov/fulltext/EJ1118940.pdf

Hui, H., Jenatabadi, H. S., Ismail, N. A., \& Jasimah, C. W. (2013). Principal's leadership style and teacher job satisfaction: A case study in China. Interdisciplinary Journal of Contemporary Research in Business, 5(4), 175-184.

https://www.researchgate.net/publication/257933785_Principal's_Leadership_Style_an d_Teacher_Job_Satisfaction_A_Case_Study_in_China

Klassen, R. M., Bong, M., Usher, E. L., Chong, W. H., Huan, V. S., Wong, I. Y. F., \& Georgiou, T. (2009). Exploring the validity of a teachers' self-efficacy scale in five countries. Contemporary Educational Psychology, 34, 67-76. https://doi.org/10.1016/j.cedpsych.2008.08.001

Koustelios, A. D. (2001). Personal characteristics and job satisfaction of Greek teachers. International Jjournal of Educational Management, 15(7), 354-358. https://doi.org/10.1108/eum0000000005931

Koutouzis, M. \& Malliara, K. (2017). Teachers' job satisfaction: The effect of principal's leadership and decision-making style. International Journal of Education, 9(4), 71-89. https://doi.org/10.5296/ije.v9i4.10272

Lent, R. W., \& Brown, S. D. (2006). Integrating person and situation perspectives on work Satisfaction: A social-cognitive view. Journal of Vocational Behavior, 69(2), 236-247. https://doi.org/10.1016/j.jvb.2006.02.006

Lester, P. E. (1987). Development and Factor analysis of the Teacher Job Satisfaction Questionnaire (TJSQ). Educational and Psychological Measurement, 47(1), 223-233. http://epm.sagepub.com/content/47/1/223

Nguni, S., Sleegers, P., \& Denessen, E. (2006). Transformational and transactional leadership effects on teachers' job satisfaction, organizational commitment, and organizational citizenship behavior in primary schools: The Tanzanian case. School Effectiveness and School Improvement, 17(2), 145-177. https://doi.org/10.1080/09243450600565746 
Nigama, K., Selvabaskar, S., Surulivel, S. T., Alamelu, R. \& Joice, D. U. (2018). Job Satisfaction among School Teachers. International Journal of Pure and Applied Mathematics, 119(7), 2645-2655. https://acadpubl.eu/jsi/2018-119-7/articles/7c/80.pdf

Persevica, A. (2011). The significance of the teacher's job satisfaction in the process of assuring quality education. Problems of Education in the 21st Century, 34, 98-109. http://journals.indexcopernicus.com/abstract.php?icid=966177

Skaalvik, E. M. \& Skaalvik, S. (2010). Teacher self-efficacy and teacher burnout: A study of relations. Teaching and Teacher Education, 26 (4), 1059-1069. https://doi.org/10.1016/j.tate.2009.11.001

Toropova, A, Myrberg, E., \& Johansson, S. (2020). Teacher job satisfaction: The importance of school working conditions and teacher characteristics. Educational Review, 73(1), 7197. https://doi.org/10.1080/00131911.2019.1705247 